\title{
Extra-intestinal localization of Goussia sp. (Apicomplexa) oocysts in Rana dalmatina (Anura: Ranidae), and the fate of infection after metamorphosis
}

\author{
M. Jirků ${ }^{1, *}$, D. Modrý ${ }^{1,2}$ \\ ${ }^{1}$ Department of Parasitology, University of Veterinary \& Pharmaceutical Sciences, Palackého 1-3, Brno, Czech Republic \\ ${ }^{2}$ Institute of Parasitology of Academy of Sciences of the Czech Republic, Branišovská 31, České Budějovice, Czech Republic
}

\begin{abstract}
Although coccidia of the genus Goussia are common parasites of fish, only 2 species have been described in amphibians: G. hyperolisi from common reed frogs Hyperolius viridiflavus from Kenya and G. neglecta from unspecified European water frogs of the genus Rana from Germany. The genus Goussia is characterized by an oocyst, with a fine oocyst wall, containing 4 dizoic sporocysts that are composed of 2 valves joined by a longitudinal suture and lacking a Stieda body (typical for the genus Eimeria). To date, infections in amphibians were generally considered to be specific to the intestine of aquatic larval stages (tadpoles) of anurans. Herein, we report on: (1) the presence of oocysts of Goussia sp. in an extra-intestinal location (liver) of tadpoles of the agile frog $R$. dalmatina and (2) the presence of oocysts in the liver of both juvenile and subadult $R$. dalmatina. These observations represent novel traits for Goussia infections in amphibians; they may explain the vertical transmission of Goussia in tadpoles.
\end{abstract}

KEY WORDS: Apicomplexa · Goussia $\cdot$ Extra-intestinal localization · Anura $\cdot$ Rana dalmatina

\section{INTRODUCTION}

Coccidian parasites are among the most prevalent and often pathogenic parasites found in vertebrates. To elucidate global population declines in amphibians in the last $20 \mathrm{yr}$, the infectious diseases found in this group of organisms have been studied (Daszak et al. 1999). The coccidian genus Goussia Labbé, 1896 comprises numerous described species, all parasitizing aquatic vertebrates, mainly fishes, amphibians (2 species) and crocodylian (1 unnamed species). The genus Goussia is characterized by oocysts, with thin (often elastic) oocyst wall, each containing 4 dizoic sporocysts. A typical feature of the genus is a longitudinal suture dividing the sporocyst wall into 2 identical valves and lacking a Stieda body (typical for the genus Eimeria) (Jirků et al. 2002).

Since members of the genus Goussia frequently parasitize commercially important fishes, species para- sitizing piscine hosts are the best-known members of the genus. Endogenous development of species parasitizing fish occurs in the gastro-intestinal tract, and/or in various internal organs (e.g. liver, spleen, kidneys) (Lom \& Dyková 1992).

In contrast to numerous Goussia spp. described from fish, only 2 species have been described from amphibians, and only 3 studies have addressed amphibian Goussia (Nöller 1920, Molnár 1995, Paperna et al. 1997). Consequently, little is known about the pathogenicity of Goussia for amphibian hosts. Two species parasitize amphibians: G. neglecta (Nöller, 1920) described from undetermined European water frogs ('Wasserfrosch' in the original description by Nöller 1920) from Germany, and G. hyperolisi Paperna, Ogara, Schein, 1997 described from a common reed frog Hyperolius viridiflavus from Kenya. Both species parasitize aquatic larval stages (tadpoles) of anurans and develop only in the intestinal epithelial cells of 
tadpoles, with sporulated oocysts of G. hyperolisi sometimes localized in the lamina propria (Paperna et al. 1997). Both Nöller (1920) and Paperna et al. (1997) reported disappearance of infection during host metamorphosis, and suggested that the Goussia infections in amphibians may be restricted to tadpoles.

We report herein on: (1) the presence of oocysts of Goussia sp. in an extra-intestinal location in tadpoles of the agile frog Rana dalmatina and (2) the presence of oocysts in the liver of both juvenile and subadult $R$. dalmatina, which represent a novel trait for Goussia infection in amphibians.

\section{MATERIALS AND METHODS}

During studies of amphibian Apicomplexa, 45 tadpoles of Rana dalmatina in developmental stages 33 to 42 (according to Gosner 1960) were collected using a dip net in the forest pond at Zajetchee potok, Brno, Czech Republic (49 $14^{\prime}$ N, 16 34 $\left.4^{\prime} \mathrm{E}\right)$, on 1 July 2004. Each tadpole was placed in a $60 \mathrm{ml}$ plastic vial containing dechlorinated tap water, and kept there for $24 \mathrm{~h}$ to defecate. Fecal samples were collected from vials by Pasteur pipette, suspended in water and examined for the presence of coccidian oocysts by a standard flotation method using modified Sheather's sucrose solution (specific gravity 1.3). Tadpoles were euthanized by pithing, dissected and processed using a standard parasitological protocol. Wet mounts (squash) preparations were made from liver, gall bladder, skin, heart and tail muscle of all examined animals. Consequently, samples of tissues from each examined tadpole or frog were fixed in $10 \%$ buffered formalin, processed routinely for histology, stained either with haematoxylin and eosin or toluidine blue, and examined for the presence of developmental stages of coccidia (endogenous development will be described elsewhere). Additionally, tadpoles of $R$. dalmatina were kept in captivity beyond metamorphosis to assess the fate of Goussia infection in metamorphosed animals. In total, 20 juvenile (and later subadult) frogs were dissected at intervals of $2 \mathrm{wk}$ for the first $2 \mathrm{mo}$, then every 1 mo for the 3rd and 4th months, and every 3 mo for the rest of the experiment up to the 15th month after metamorphosis. The last specimen was dissected at the end of the 15th mo after metamorphosis. Experimental frogs were housed in $15 \mathrm{l}$ plastic vivaria and fed with crickets Gryllus assimilis, daily for the first 2 mo and 3 times a week for the rest of the experiment. Samples from experimental frogs were processed as described above.

All observations were made on an Olympus AX 70 microscope equipped with a calibrated ocular micrometer. Nomarski interference contrast optics (NIC) were used for squash native preparations. Measurements (length $\times$ width) and shape index (SI, length/width ratio) are reported in micrometres, as mean values, followed by the range in parentheses. Due to uncertainty on the species level, we refer to our isolates as Goussia sp. throughout the text.

\section{RESULTS}

\section{Examination of tadpoles}

Examination of fecal debris by flotation revealed 23 of $45(51 \%)$ tadpoles shedding oocysts of Goussia sp. According to examination of wet mounts using NIC, all 45 examined tadpoles possessed oocysts of Goussia sp. in the intestine and liver, but not in other organs examined. Oocysts with an elastic oocyst wall, tightly surrounding the sporocysts and enclosed in a so-called yellow body (YB) were frequently observed, either individually or in clusters of up to 4 oocysts (Fig. 1A). Free oocysts or sporocysts (when oocysts were crushed mechanically during wet mount preparation) (Fig. 1B) were most frequently encountered in liver mounts. There was no significant morphological difference between sporocysts from the intestine $[7.4(7.0-8.0) \times$ 4.7 (4.0-5.0), SI = $1.6(1.4-1.9), \mathrm{n}=50]$ and liver [7.5 $(7.0-8.0) \times 4.7(4.0-5.0), \mathrm{SI}=1.6(1.4-1.8), \mathrm{n}=50]$. The suture dividing the sporocyst wall into 2 plates was occasionally seen on the sporocyst wall surface in wet mount preparations using NIC, though barely visible. Only sporulated oocysts (or sporocysts) were observed in all wet mounts.

Histological examination of the intestine of tadpoles revealed developmental stages of Goussia sp., mostly sporulating oocysts and rarely gamonts in various stages of maturity. In liver tissue, only fully sporulated oocysts were observed, either free (Fig. 1C), within a YB (Fig. 1D), or inside macrophages (Fig. 1E to G) in histological sections. All oocysts observed in the liver were localized in sinuses; no oocysts were observed inside the hepatocytes or other liver cells. In most cases, oocysts observed in the liver were associated with clusters of granular material resembling hemosiderin (Fig. 1C, G), regardless of whether they were free, in YBs, or in macrophages. YBs, containing oocysts, were often composed of the multilamellar substance originating from former host cells (Fig. 1D). Generally, intensity of liver infection in tadpoles was low to moderate, always less than in the intestine.

\section{Examination of frogs after metamorphosis}

All juvenile and subadult experimental frogs $(\mathrm{n}=20)$ examined from $2 \mathrm{wk}$ to 15 mo after metamorphosis 


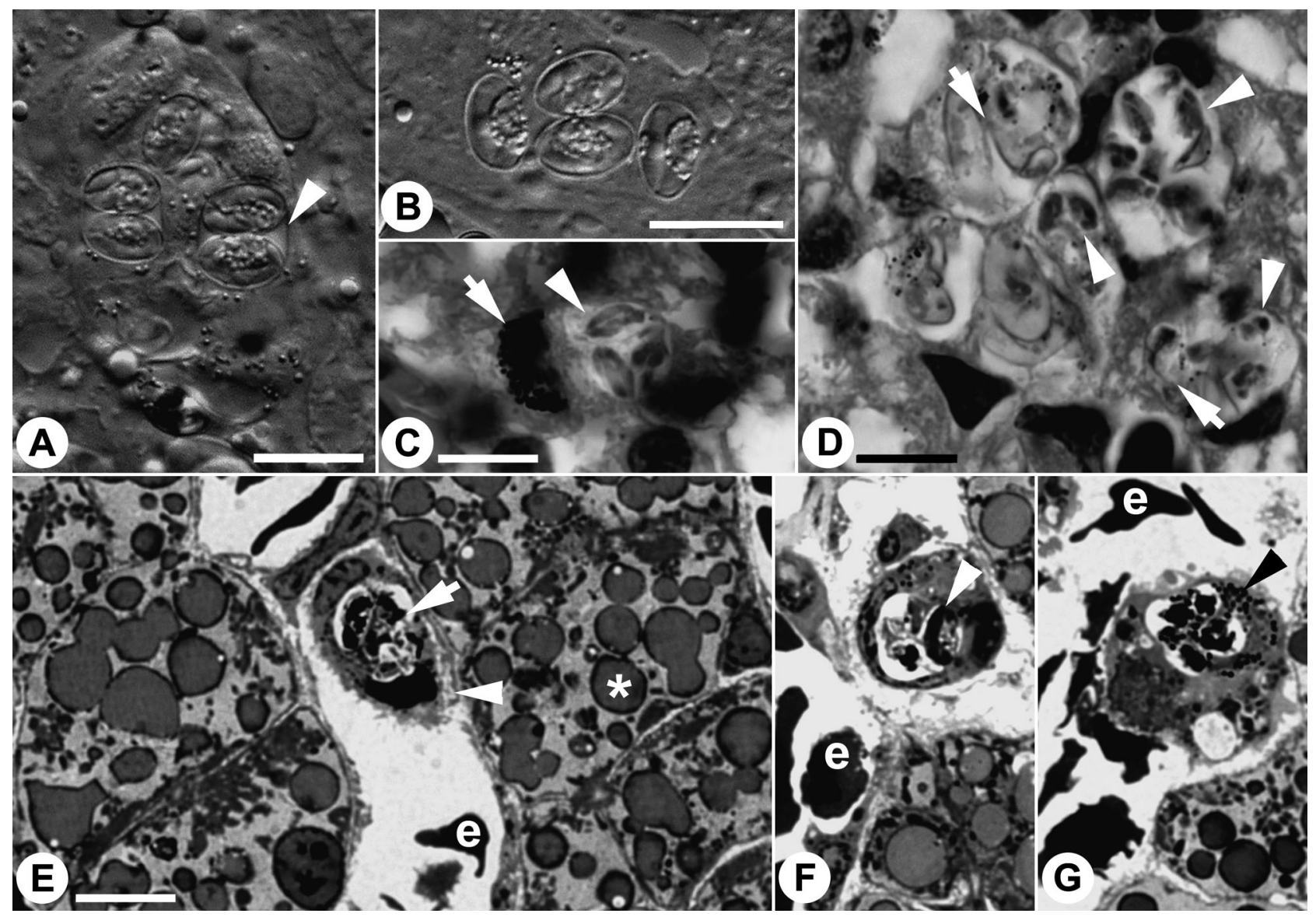

Fig. 1. Goussia sp. infecting Rana dalmatina. Micrographs of oocysts in the liver of tadpoles. (A) Three oocysts enclosed in a yellow body formed by dystrophic host cell(s). Note clearly visible elastic oocyst wall (arrowhead); wet mount, NIC (Nomarski interference contrast optics). (B) Sporocysts released mechanically from the oocyst during squash preparation; wet mount, NIC. (C) Oocyst (arrowhead) within liver sinus, with distinct cluster of hemosiderin-like granules (arrow); hematoxylin and eosin (H \& E). (D) Several oocysts (arrowheads) enclosed by a YB within the liver sinus. Note YB is partly formed by lamellar structures (arrows) originating from former host cell(s) cytoplasm; H \& E. (E) Overview of the liver sinus with 1 macrophage (arrowhead) containing a single oocyst (arrow). Note numerous lipid droplets $(*)$ typical for hepatocytes of anuran tadpoles, and erythrocytes (e); toluidin blue. (F) Macrophage with phagocytosed oocyst clearly showing sporozoite arrangement inside sporocyst (arrowhead); toluidine blue. (G) Macrophage showing oocyst within its cytoplasm and distinct hemosiderin-like granules (arrowhead) in its cytoplasm; toluidine blue. Scale bars $=10 \mu \mathrm{m}$ (A to $\mathrm{E}) ;(\mathrm{C}$ to $\mathrm{G})$ are of the same scale

possessed oocysts of Goussia sp. in liver in wet mount preparations (Fig. 2A). In these animals, only individual or clustering oocysts were observed, not enclosed by YBs or macrophages. In metamorphosed specimens, oocysts were always within clusters of hemosiderin-like granular material within liver sinuses in histological sections (Fig. 2B). No Goussia sp. stages were detected in the intestine in metamorphosed frogs $>4$ d after metamorphosis.

\section{DISCUSSION}

To date, only a single species of Goussia, namely $G$. neglecta, has been described from Holarctic amphib- ians. Although being originally assigned to the genus Eimeria by Nöller (1920), it was later transferred to the genus Goussia by Molnár (1995). Reports of both authors were based on the material obtained from semi-aquatic 'water frogs' (either Rana kl. esculenta or $R$. ridibunda, and possibly also $R$. lessonae in Nöller's study).

Measurements of sporocysts of our isolate differ slightly from (though overlap with) those in the original description of Goussia neglecta and as reported by Molnár (1995). Since narrow host specificity of some Goussia spp. parasitizing fish has recently been confirmed experimentally (Molnár et al. 2005), and no experimental cross-infections were carried out in our study, it is uncertain whether our isolates from phylo- 


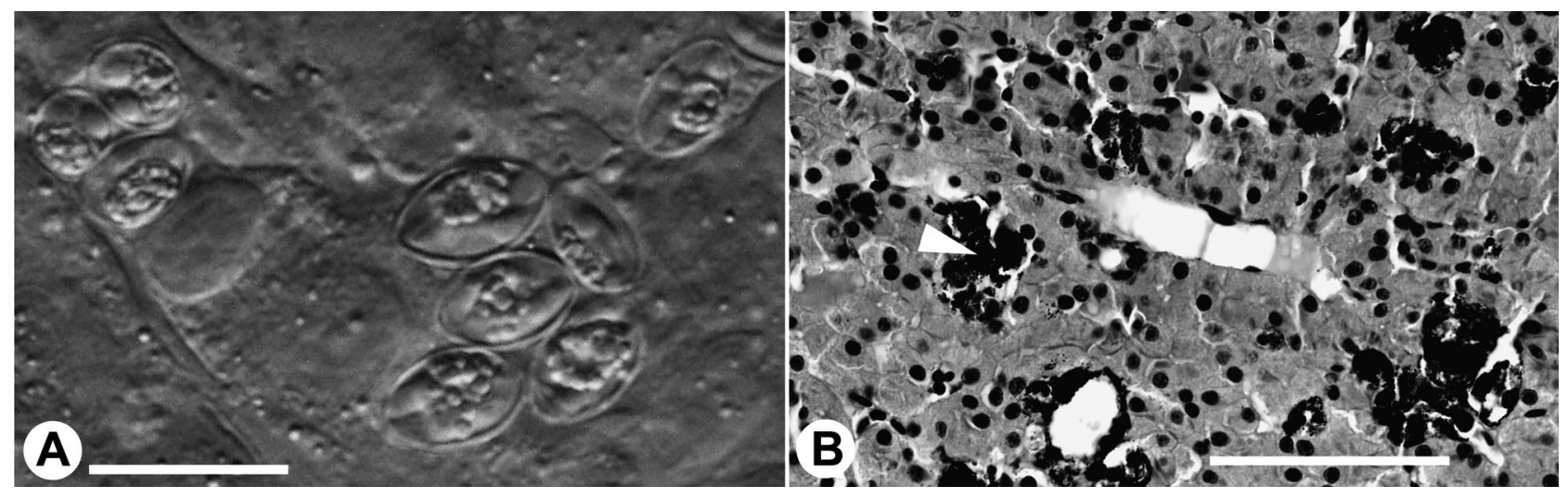

Fig. 2. Goussia sp. infecting Rana dalmatina. Micrographs of the preparations from experimental subadult tadpoles, 15 mo after metamorphosis. (A) Sporocysts from 3 mechanically ruptured Goussia sp. oocysts in the liver. Note: Sporocysts do not show any signs of degradation even after 15 mo within the host; wet mount, NIC. (B) Cross-section of the liver. Oocysts, sometimes in groups of up to 3, were typically located within liver sinuses, obscured by aggregations of pigment granules (arrowhead), typical for liver of most tetrapod poikilotherm vertebrates. Scale bars $=10 \mu \mathrm{m}(\mathrm{A}) ; 100 \mu \mathrm{m}(\mathrm{B})$

genetically and ecologically distant Rana dalmatina represent $G$. neglecta or a separate species. Crosstransmission experiments and molecular data are necessary to clarify the taxonomic status of the isolate reported herein, since no semi-aquatic green frogs of the genus Rana (type host) occur syntopically at the study site. Due to synchronized sporogony and morphological identity, we believe that stages of Goussia observed in the tadpoles' liver and intestine throughout our study are conspecific.

This is the first observation of Goussia in an extraintestinal location in an amphibian host. The ability to undergo endogenous development in extra-intestinal organs occurs in a few Goussia spp. infecting fish. For example, G. alburni (Stankovitch, 1920) develops in the intestine, periintestinal fat tissue, kidneys, liver, spleen, muscles, urinary bladder, brain, swim bladder and gills (Lukeš 1990, Lom \& Dyková 1992). However, the way of migration of infective stages to extra-intestinal tissue is unclear (Fiebiger 1913, Desser 1981, Fournie \& Overstreet 1983).

All oocysts in tadpole liver were fully sporulated, located in liver sinuses and usually associated with granular, hemosiderin-like material, probably originating from macrophages. This granular material was not observed in intestinal infections. No developmental stages other than sporulated oocysts were detected in the livers of 45 tadpoles. Thus, we believe that oocysts are transported to the liver by macrophages during the hosts' larval development.

We observed the presence of YBs containing oocysts only in tadpoles (but not in metamorphosed frogs); this is a typical feature of Goussia infections in both anurans (Paperna et al. 1997) and fish (Lom \& Dyková 1992). In tadpoles, YBs observed in the intestine are formed by dystrophic host cells (enterocytes). In the liver, YBs are formed by dystrophic macrophages as inferrred by the presence of hemosiderin-like material observed inside both live macrophages (Fig. 1G) and YBs (Fig. 1A). The absence of YBs in the livers of juvenile and subadult frogs is probably caused by YB disintegration, leaving only free oocysts and hemosiderinlike material within liver sinuses.

Populations of tadpoles face high predation pressure and also exhibit high natural mortality (Denton \& Beebee 1997, Loman 2004). The most probable ways that Goussia sp. oocysts leave the liver of a host is either after the host's death, or via the feces of a predator.

In our study, the prevalence of Goussia sp. was $51 \%$ in tadpole feces as determined by 1 -shot examination. Careful inspection of the intestinal and hepatic tissues by squash preparation confirmed the presence of oocysts in both organs in $100 \%$ of the individuals examined. This contradiction, caused by intermittent oocyst discharge, might indicate that oocysts are released from the intestinal tissue irregularly in high numbers from deeper layers of intestinal mucosa. This process could be associated either with epithelial regeneration after necrosis of infected cells, or with rapid cell turnover of intestinal epithelium during the hosts' metamorphosis.

The disappearance of Goussia sp. infection from the intestine of tadpoles during metamorphosis, as reported by Nöller (1920) and Paperna et al. (1997), corresponds well with our observations. However, we confirmed the ability of Goussia sp. to persist within hosts through the complex process of metamorphosis, with oocysts being detected in the liver as long as 15 mo after metamorphosis. Due to high prevalence (100\% in our study), extra-intestinal oocysts may be 
important reservoirs when a new breeding site is colonized by frogs or when a breeding site dries out. Oocysts of Goussia sp. are not likely to leave adult hosts via feces. The mortality of adult frogs, when cadavers are later consumed by tadpoles, may represent an alternative route of transmission of Goussia infection.

Acknowledgements. This study was supported by grants from the grant agency of the Czech Republic (Nos. 206/03/1544 and 524/03/H133). We thank Renata Tallová (SVKOL, Olomouc, Czech Republic) for her kind help in obtaining the literature, and Věra Kučerová, Blanka Cikánová (ÚEM CAS), Monika Schcherlová and Marie Flašková (PAU CAS) for their generous help in processing the samples.

\section{LITERATURE CITED}

Daszak P, Berger L, Cunningham AA, Hyatt AD, Green DE, Speare R (1999) Emerging infectious diseases and amphibian population declines. Emerg Infect Dis 5:735-748

Denton JS, Beebee TJC (1997) Effects of predator interactions, prey palatability and habitat structure on survival of natterjack toad Bufo calamita larvae in replicated seminatural ponds. Ecography 20:166-174

Desser SS (1981) The challenge of fish coccidia. J Protozool 28:260-261

Fiebiger J (1913) Studien über die Schwimmblasencoccidien der Gadusarten (Eimeria gadi n. sp.). Arch Protistenkd 31: 95-137

Editorial responsibility: Otto Kinne (Managing Editor), Oldendorf/Luhe, Germany
Fournie JW, Overstreet RM (1983) True intermediate hosts for Eimeria funduli (Apicomplexa) from estuarine fishes. J Protozool 30:672-675

Gosner KL (1960) A simplified table for staging anuran embryos and larvae with notes on identification. Herpetologica 16:225-232

Jirků M, Modrý D, Slapeta JR, Koudela B, Lukes J (2002) The phylogeny of Goussia and Choleoeimeria (Apicomplexa; Eimeriorina) and the evolution of excystation structures in coccidia. Protist 153:379-390

Lom J, Dyková I (1992) Protozoan parasites of fishes. Elsevier, Amsterdam

Loman J (2004) Density regulation in tadpoles of Rana temporaria: a full pond field experiment. Ecology 85:1611-1618

Lukeš J (1990) Kokcidie sladkovodních ryb (druhová skladba v ČR, biologie a ultrastruktura). PhD dissertation, Academy of Sciences of the Czech Republic, České Budějovice

Molnár K (1995) Redescription of Goussia neglecta n. comb. (Noller, 1920) (Apicomplexa: Coccidia) and notes on its occurrence in the gut of tadpoles. Acta Vet Hung 43: $269-275$

Molnár K, Ostoros G, Baska F (2005) Cross-infection experiments confirm the host specificity of Goussia spp. (Eimeriidae: Apicomplexa) parasitizing cyprinid fish. Acta Protozool 44:43-49

Nöller W (1920) Zur Kenntnis der Coccidien des Wasserfrosches (Eimeria neglecta nov. spec.) (Befruchtung und Sporogonie von Lankesterella). Arch Protistenkd 41: 176-180

Paperna I, Ogara W, Schein M (1997) Goussia hyperolisi n. sp.: a coccidian infection in reed frog Hyperolis viridiflavus tadpoles which expires towards metamorphosis. Dis Aquat Org 31:79-88

Submitted: December 1, 2005; Accepted: March 3, 2006

Proofs received from author(s): June 16, 2006 